\title{
Susceptibility of IFN- $\gamma$ or IL-12 knock-out and SCID mice to infection with two microsporidian species, Encephalitozoon cuniculi and $E$. intestinalis
}

\author{
Jiří Salát ${ }^{1}$, Bohumil Sak $^{1}$, Thuy Le ${ }^{2}$ and Jan Kopecký ${ }^{1}$ \\ ${ }^{1}$ Institute of Parasitology, Academy of Sciences of the Czech Republic and Faculty of Biological Sciences, University of South \\ Bohemia, Branišovská 31, 37005 České Budějovice, Czech Republic; \\ ${ }^{2}$ Medical School of the University of Arizona, Tucson, AZ 85724, USA
}

Key words: Microsporidia, Encephalitozoon intestinalis, Encephalitozoon cuniculi, IFN- $\gamma$ knock-out, IL-12 knock-out, SCID mice

\begin{abstract}
Susceptibility of three strains of immunodeficient mice to two related microsporidian species Encephalitozoon cuniculi Levaditi, Nicolau et Schoen, 1923 and Encephalitozoon intestinalis (Cali, Kotler et Orenstein, 1993) was compared. While both, severe combined immunodeficient (SCID) and interferon-gamma knock-out (IFN- $\gamma$ KO) mice, succumbed to either intraperitoneal (i.p.) or peroral (p.o.) (natural) infection with both parasites, only i.p. infection with E. cuniculi killed interleukin-12 knock-out (IL-12 KO) mice. IFN- $\gamma$ KO mice died earlier than SCID mice. Adoptive transfer of naive splenocytes from IFN- $\gamma$ KO mice did not protect the SCID mice from a lethal infection with either of the Encephalitozoon species. However, reconstituted mice survived significantly longer $(\mathrm{P}<0.05)$, thus indicating the role of IFN- $\gamma$ produced by host NK cells in the development of mechanisms of anti-microsporidial protective immunity. Non-lethal outcome of the infection always correlated with the increase in CD8+ T lymphocyte subpopulation. Both E. intestinalis-infected IFN- $\gamma \mathrm{KO}$ and IL-12 KO mice produced comparable levels of specific antibodies, suggesting that antibodies did not protect IFN- $\gamma \mathrm{KO}$ mice from lethal infection.
\end{abstract}

Microsporidia are obligate intracellular parasites causing opportunistic infections in immunocompromised hosts (Orenstein 1991, Weber et al. 1994). With the onset of AIDS becoming pandemic, more attention has been paid to microsporidian genera Encephalitozoon, Enterocytozoon, Pleistophora, Trachipleistophora, Nosema and Thelohania (Didier et al. 1998). In immunocompromised host, microsporidia infect various internal organs with possible lethal outcome while, in immunocompetent hosts, latent infections are often established which remain asymptomatic as long as parasite multiplication and host immune response are balanced (Gannon 1980, Schmidt and Shadduck 1983).

Most of what is known about the host immune response against microsporidia is based on the intraperitoneal infection of mice with Encephalitozoon cuniculi Levaditi, Nicolau et Schoen, 1923 (Khan et al. 2001). Cell-mediated immunity has been demonstrated to be critical for the survival of E. cuniculi-infected host. An early response of cytotoxic CD8+ T lymphocytes developed, reducing the parasite load by killing infected host cells via perforin pathway (Khan et al. 1999). Induction of the CD8+ T cell response was independent of CD4+ T lymphocytes, the role of which was substituted by $\gamma \delta$ T lymphocytes (Moretto et al. 2000, 2001). Both IL-12 and IFN- $\gamma$ were proven to be critical for the development of anti-microsporidial protective immunity (Khan and Moretto 1999). The role of IL-12 and IFN- $\gamma$ likely consists of the polarisation towards Th1 immune responses; moreover, IFN- $\gamma$ is important for induction and maintaining of $\mathrm{CD} 8+\mathrm{T}$ cell responses. The other possible role of IFN- $\gamma$ in anti-microsporidial immunity is rather controversial. Whereas IFN- $\gamma$-activated macrophages in vitro killed microsporidia by mechanisms dependent on reactive nitrogen intermediates (Didier 1995), in vivo IFN- $\gamma$-mediated protection against $E$. cuniculi infection was independent of nitric oxide production (Khan et al. 1999).

Less is known about the host immune response against Encephalitozoon intestinalis (Cali, Kotler et Orenstein, 1993). The parasite develops in enterocytes of the small intestine and in an immunocompromised host it also infects the macrophages of the lamina propria, thereby being disseminated to the kidney and hepatobiliary tract. IFN- $\gamma$ receptor knock-out (KO) mice develop a chronic infection, whereas transient infection develops in wild-type mice (El Fakhry et al. 2001). In resistant mice, Th1 immune response is manifested, whereas highly susceptible IFN- $\gamma$ receptor $\mathrm{KO}$ mice produce high levels of Th2 cytokines IL-4 and IL-10. The knock-out mice produce higher levels of anti-microsporidial antibodies (including IgA) compared to wild-type mice indicating an insignificant role of humoral immunity in the recovery from microsporidial infection (El Fakhry et al. 1998).

Most data on the anti-microsporidial immunity have been obtained after intraperitoneal (i.e. artificial) inoculation. Recently, it has been demonstrated that the sig- 
nificance of CD4+ and CD8+ T lymphocytes in the protection of mice against $E$. cuniculi infection differs markedly depending on the route of infection (Braunfuchsová et al. 2002). Whereas CD8+ T cells are critical for the protection against an intraperitoneal inoculation, both CD4+ and CD8+ T lymphocytes play a substantive protective role in a peroral (i.e. natural) route of inoculation. In the present study, we compare both routes of inoculation with E. cuniculi and E. intestinalis in three immunodeficient strains of mice, SCID, IFN- $\gamma \mathrm{KO}$ and IL-12 KO mice.

\section{MATERIALS AND METHODS}

Parasites. Encephalitozoon cuniculi, strain EC2 originally isolated from dexamethasone-treated laboratory mouse (Koudela et al. 1994), was grown in VERO E6 cells for provision of spores. Cells were cultivated in RPMI 1640 medium supplemented with $2.5 \%$ foetal calf serum (FCS). The spores were purified by centrifugation over $50 \%$ Percoll (Pharmacia), washed three times in deionized water and stored in deionized water with antibiotics $(100 \mathrm{U} / \mathrm{ml}$ penicillin, $100 \mu \mathrm{g} / \mathrm{ml}$ streptomycin, $2.5 \mu \mathrm{g} / \mathrm{ml}$ amphotericin; Sigma Aldrich) at $4^{\circ} \mathrm{C}$ not longer than one week. Before inoculation, the spores were washed in PBS.

Encephalitozoon intestinalis originally isolated from an AIDS patient by Didier (1996) was grown in VERO E6 cells for provision of spores. Production and purification of spores was the same as for E. cuniculi.

Mice. Mice with a disrupted IFN- $\gamma$ gene (strain C.1297S7 (B6)-Ifng ${ }^{\text {tmlTs }}$ ) of the BALB/c background and mice with a disrupted gene coding for IL-12 (strain B6.129-I112 $\mathrm{b}^{\mathrm{tm} 1 \mathrm{Jm}}$ ) of the C57BL/6 background were obtained from The Jackson Laboratory, Bar Harbor, Maine, USA. SCID mice (strain C.B17) of the BALB/c background were originally obtained from Dr. G.C. Bosma (Fox Chase Center, Philadelphia, USA). Mice were housed in flexible film isolators (BEM Znojmo, Czech Republic) with high-efficiency particulate air (HEPA) filters and supplied sterilized diet and water ad libitum. BALB/c and C57BL/6 female mice of 7-9 weeks of age were purchased from Charles River Laboratory, Germany. Throughout the experiments, mice were fed standard rodent diet and drinking water ad libitum. They were caged in a mouse room with the temperature kept at $22^{\circ} \mathrm{C}$, RH $65 \%$. Mice aged 8 weeks, at the moment of infection, were used throughout the experiments. Before harvesting splenocytes or peritoneal exudate cells the mice were humanely killed.

Infection of mice. Groups of 5 SCID, IFN- $\gamma$ KO, IL-12 $\mathrm{KO}, \mathrm{BALB} / \mathrm{c}$ and $\mathrm{C} 57 \mathrm{BL} / 6$ mice were inoculated with a dose of $10^{7}$ spores of E. cuniculi or E. intestinalis intraperitoneally (i.p.) or per os (p.o.). I.p. inoculation was carried out in $0.1 \mathrm{ml}$ PBS; p.o. infection was performed by intragastric gavage of $0.1 \mathrm{ml}$ suspension of spores in water. The mice were evaluated daily for signs of morbidity or mortality.

Groups of 3 SCID, IFN- $\gamma$ KO, IL- $12 \mathrm{KO}, \mathrm{BALB} / \mathrm{c}$ and $\mathrm{C} 57 \mathrm{BL} / 6$ mice inoculated the same way were used for monitoring of microsporidia-specific antibodies. Blood was collected from retroorbital sinus at various time points post inoculation (p.i.) as indicated in Results, and specific anti- bodies were determined in serum by enzyme-linked immunosorbent assay (ELISA).

Groups of 3 IFN- $\gamma$ KO, IL-12 KO, BALB/c and C57BL/6 mice experimentally infected with both parasites as mentioned above were used for immunophenotypic analysis (CD4+, CD8+ T lymphocytes) by flow cytometry. The analysis of splenocytes was performed on days 7 and 14 p.i.

Adoptive transfer experiment. Whole splenocytes were obtained by mechanical disruption of the spleen and washed three-times in RPMI-1640 medium. SCID mice were reconstituted with an i.p. dose of $10^{7}$ splenocytes from naive IFN- $\gamma$ KO mice in $0.2 \mathrm{ml}$ RPMI-1640 medium without serum. Seven days after the adoptive transfer, groups of 5 mice were infected with $10^{7}$ spores of E. cuniculi or E. intestinalis either i.p. or p.o. as mentioned above. Morbidity and mortality of mice were recorded daily. Control groups of 5 SCID mice were experimentally infected the same way.

Four groups of 6 reconstituted SCID mice identically infected were analysed for the expression of CD4 and CD8 molecules on their splenocytes by flow cytometry. The analysis was performed on days $20,25,30$ and 45 p.i. depending on the survival of individual groups. Splenocytes from three mice were analysed in each interval. The reconstituted non-infected control group was analysed on day 27 after reconstitution, corresponding to day 20 p.i.

Serum antibody assay. To measure the relative levels of microsporidia-specific serum antibodies, an ELISA method was used. Tissue culture-derived E. intestinalis or E. cuniculi spores were adjusted to $1 \times 10^{7} / \mathrm{ml}$ in coating buffer and 100 $\mu 1$ was added to each well of 96 -well ELISA plates. The plates were incubated overnight at $4^{\circ} \mathrm{C}$. Then the plates were allowed to dry and were fixed with a 1:1 mixture of acetone and methanol for $10 \mathrm{~min}$ at room temperature. After blocking the unbound sites with $5 \%$ newborn calf serum (NBCS) in PBS for one hour at $37^{\circ} \mathrm{C}$ the plates were washed with $0.05 \%$ Tween 20-PBS (T-PBS) three times and incubated with test sera diluted 1:100 in $2 \%$ NBCS in PBS for one hour at $37^{\circ} \mathrm{C}$. The plates were then washed with T-PBS and incubated with peroxidase-conjugated swine anti-mouse IgG (Sevak, Prague, Czech Republic) diluted 1:2000 in 2\% NBCS in PBS for one hour at $37^{\circ} \mathrm{C}$. After washing, an enzymatic colour reaction was generated using orthophenylenediamine substrate, stopped after 10 min with $100 \mu \mathrm{m}$ of $2 \mathrm{M} \mathrm{H}_{2} \mathrm{SO}_{4}$ and measured at $490 \mathrm{~nm}$ with an ELISA spectrophotometer (Labsystem Multiskan, Labsystems Oy, Helsinki, Finland). Results represent the mean of three wells.

Flow cytometry analysis. Splenocytes were analysed by flow cytometry. CD4-specific monoclonal antibody (MAb) YTS 177.9 (conjugated with fluorescein isothiocyanate) and CD8-specific MAb KT15 (conjugated with phycoerythrin) (Serotec) were used for the phenotypic analysis. Samples $\left(10^{6}\right.$ cells) were incubated with $100 \mu \mathrm{l}$ of antibody $(10 \mu \mathrm{g} / \mathrm{ml})$ in PBS with $1 \% \mathrm{FCS}$ for $30 \mathrm{~min}$ at $4^{\circ} \mathrm{C}$. After washing with icecold PBS with $1 \%$ FCS, the cells were used for FACS analysis. Cell analysis was performed on an Epics XL Flow Cytometer (Coulter) equipped with a $15-\mathrm{mW}$ argon-ion laser with excitation capabilities at $488 \mathrm{~nm}$. Ten thousand events of viable cells were measured in each suspension. The labelled cell population was analysed using WinMDI software (Coulter). 
Statistical analysis. The significance of any differences in percentage or absolute numbers of $\mathrm{T}$ cell subsets between experimental groups was evaluated by analysis of variance (oneway ANOVA). Differences in survival between groups of infected mice were analysed by non-parametric Mann-Whitney $U$-test.

\section{RESULTS}

Comparison of time to death in four groups of SCID mice infected with two microsporidia species $E$. cuniculi and E. intestinalis either i.p. or p.o. (Fig. 1) showed that there was almost no difference between groups of mice infected with these parasites i.p. The mean survival time (MST) was $20.4 \pm 1.8$ days for E. cuniculiinfected group and $21.4 \pm 2.1$ days for E. intestinalisinfected group. In perorally infected mice, a delay of time to death $(\mathrm{P}=0.05)$ was recorded compared to i.p. infected groups. E. cuniculi-infected mice died earlier (MST $=34.4 \pm 4.5$ days) than E. intestinalis-infected mice (MST $=40.0 \pm 3.9$ days).

To determine the role of IFN- $\gamma$ and IL-12 in antimicrosporidial protective immunity, groups of IFN- $\gamma$ $\mathrm{KO}$ and IL-12 KO mice were infected with one or the other Encephalitozoon species i.p. or p.o. (Figs. 2, 3). IFN- $\gamma \mathrm{KO}$ mice infected with $E$. intestinalis i.p. died even earlier $(\mathrm{MST}=14.6 \pm 0.8$ days) than SCID mice infected the same way (MST $=21.4 \pm 2.1$ days). Similarly, IFN- $\gamma$ KO mice infected with E. cuniculi i.p. succumbed to infection by 4 days earlier than SCID mice $(\mathrm{MST}=16.2 \pm 0.8$ days and $20.4 \pm 1.8$ days, respectively). Perorally infected IFN- $\gamma$ KO mice also succumbed to both parasites, but there was no difference from SCID mice in time to death. The mean survival time was $38.6 \pm 5.3$ days and $33.2 \pm 5.4$ days in IFN- $\gamma$ KO mice infected with E. intestinalis and E. cuniculi, respectively. The corresponding MST values in SCID mice were $40.0 \pm 3.9$ days and $34.4 \pm 4.5$ days. Only IL$12 \mathrm{KO}$ mice infected with E. cuniculi i.p. died with MST $=63.4 \pm 11.5$ days. No death was recorded in the remaining groups of IL-12 KO mice until the end of the experiment (day 90 p.i.). Similarly, immunocompetent BALB/c mice (wild-type counterpart of IFN- $\gamma \mathrm{KO}$ ) and C57BL/6 (wild-type counterpart of IL-12 KO) infected with E. intestinalis or E. cuniculi i.p. or p.o. survived until the termination of the experiment (day 90 p.i.).

To determine the role of IFN- $\gamma$ produced by the cells of natural non-specific immunity (e.g., NK cells) in the induction of protective immunity against microsporidia, SCID mice were reconstituted with splenocytes from IFN- $\gamma$ KO mice and infected with E. cuniculi or $E$. intestinalis i.p. or p.o. Mice in all experimental groups ultimately succumbed to the infection (Fig. 4). Reconstituted animals showed similar mortality dynamics as non-reconstituted SCID mice with two differences. The time to death was delayed in all groups of reconstituted animals. The MST in reconstituted SCID mice was 36.0 \pm 6.2 days and $51.8 \pm 6.7$ days after infection with

\section{1}

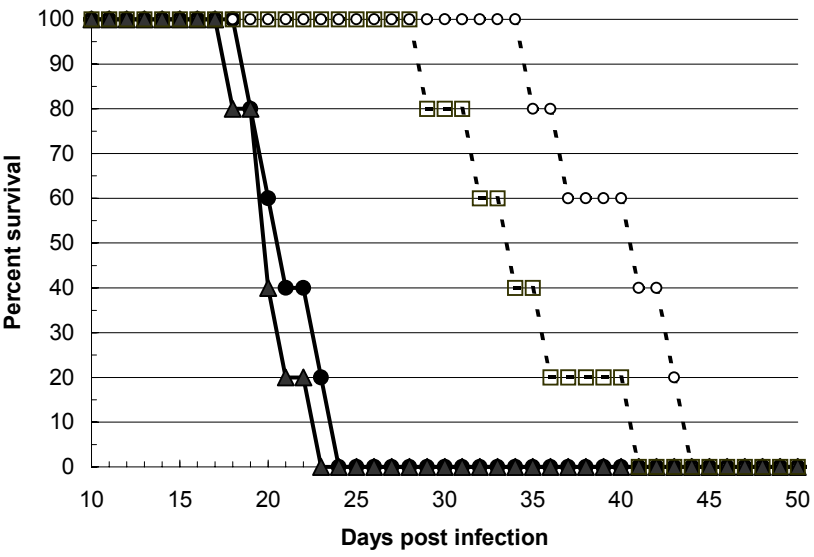

\section{2}

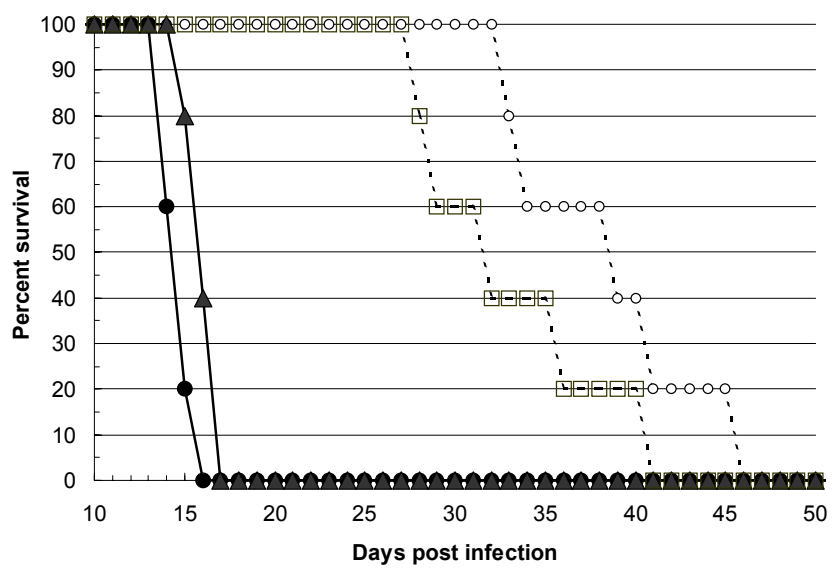

\section{3}

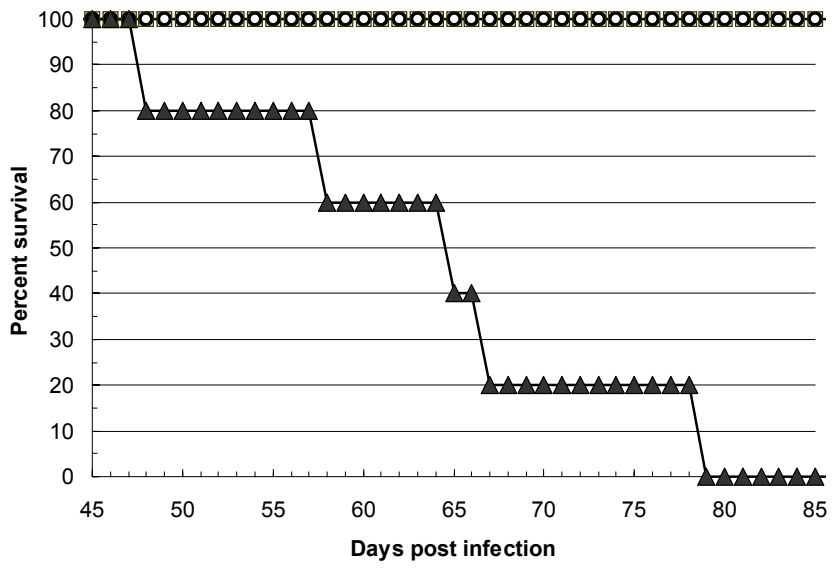

-๑-E. intestinalis - i.p. infection --०-- E. intestinalis - p.o. infection $-\boldsymbol{\Delta}-$ E. cuniculi - i.p. infection --口-- E. cuniculi-p.o. infection

Figs. 1-3. Survival of mice from i.p. or p.o. infection with Encephalitozoon intestinalis or E. cuniculi. Groups of 5 mice were infected with a dose of $10^{7}$ spores. Mortality was monitored on a daily basis. Fig. 1. SCID mice. Fig. 2. IFN- $\gamma$ KO mice. Fig. 3. IL-12 KO mice. 


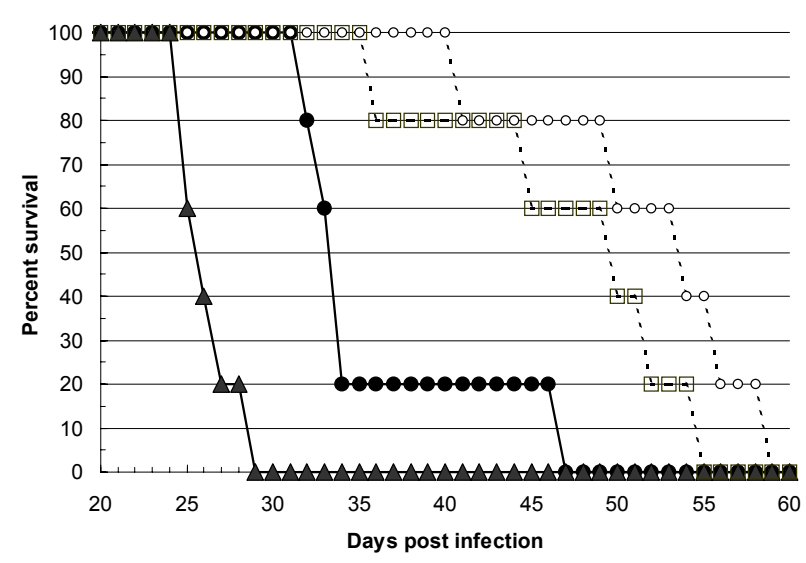

-๑-E. intestinalis - i.p. infection --०-- E. intestinalis - p.o. infection $-\mathbf{\Delta}-$ E. cuniculi - i.p. infection $\quad--\square--$ E. cuniculi-p.o. infection

Fig. 4. Survival of SCID mice reconstituted with splenocytes from naive IFN- $\gamma \mathrm{KO}$ mice from i.p. or p.o. infection with Encephalitozoon intestinalis or E. cuniculi. $10^{7}$ splenocytes from naive IFN- $\gamma \mathrm{KO}$ mice were injected i.p. into groups of 5 SCID mice. Seven days after the adoptive transfer, the mice were infected with a dose of $10^{7}$ spores. Mortality was monitored on a daily basis. The difference between groups of mice injected i.p. with E. intestinalis and E. cuniculi was significant at $\mathrm{P}<0.05$.
E. intestinalis i.p. and p.o., respectively, and $26.4 \pm 1.7$ days and $47.6 \pm 7.4$ days after infection with $E$. cuniculi. The second difference was in the mortality dynamics after peroral infection with individual Encephalitozoon species. In contrast to non-reconstituted SCID mice, reconstituted SCID mice died later after infection with $E$. intestinalis compared with those infected with $E$. cuniculi.

Flow cytometry analysis was performed in control and infected IFN- $\gamma \mathrm{KO}$ and IL-12 KO mice and in their wild-type counterparts, $\mathrm{BALB} / \mathrm{c}$ and $\mathrm{C} 57 \mathrm{BL} / 6$ mice. Seven days after infection of IFN- $\gamma \mathrm{KO}$ mice with $E$. intestinalis either i.p. or p.o., a significant decrease of CD4+ and CD8+ cells was recorded either in the percentage or in absolute numbers $(\mathrm{P}<0.05)$ (Table 1$)$. Fourteen days post peroral infection, absolute numbers of both T lymphocyte subsets slightly increased, but the percentage of positive cells remained lower compared with the control, probably due to splenomegaly. Results of flow cytometry analysis of IFN- $\gamma \mathrm{KO}$ mice infected with E. cuniculi were comparable to those obtained with $E$. intestinalis infection. An increase in the absolute number of CD8+ cells 14 days after p.o. infection with E. cuniculi was accompanied with the percentage increase of these cells above the control value $(\mathrm{P}<0.05)$.

Table 1. Flow cytometry analysis of splenocytes from IFN- $\gamma \mathrm{KO}$ mice infected with Encephalitozoon intestinalis and E. cuniculi i.p. or p.o.

\begin{tabular}{|c|c|c|c|c|c|c|}
\hline & & \multirow[b]{2}{*}{ Days p.i. } & \multicolumn{2}{|c|}{ CD4+ } & \multicolumn{2}{|c|}{ CD8+ } \\
\hline & & & $\%$ Positive & Abs. No. * & $\%$ Positive & Abs. No. * \\
\hline Control & & & $22.30 \pm 0.04$ & $14.94 \pm 1.21$ & $9.00 \pm 0.09$ & $6.03 \pm 0.65$ \\
\hline \multirow[b]{2}{*}{$\begin{array}{l}\text { Encephalitozoon } \\
\text { intestinalis }\end{array}$} & i.p. & 7 & $16.20 \pm 0.12^{\mathrm{P}}$ & $11.34 \pm 0.75^{\mathrm{P}}$ & $6.10 \pm 0.21^{P}$ & $4.27 \pm 0.33^{\mathrm{P}}$ \\
\hline & p.o. & $\begin{array}{c}7 \\
14\end{array}$ & $\begin{array}{l}17.10 \pm 0.23^{\mathrm{P}} \\
16.30 \pm 0.08^{\mathrm{P}}\end{array}$ & $12.82 \pm 0.83^{P}$ & $\begin{array}{l}7.50 \pm 0.13^{\mathrm{P}} \\
7.80+016^{\mathrm{P}}\end{array}$ & $5.62 \pm 0.62$ \\
\hline \multirow[b]{2}{*}{$\begin{array}{l}\text { Encephalitozoon } \\
\text { cuniculi }\end{array}$} & i.p. & 7 & $17.60 \pm 0.33^{P}$ & $11.61 \pm 1.79^{\mathrm{P}}$ & $9.20 \pm 0.25$ & $6.07 \pm 0.47$ \\
\hline & p.o. & $\begin{array}{c}7 \\
14\end{array}$ & $\begin{array}{l}16.30 \pm 0.05^{\mathrm{P}} \\
18.20 \pm 0.41^{\mathrm{P}}\end{array}$ & $\begin{array}{c}12.50 \pm 0.58^{P} \\
13.10 \pm 0.26\end{array}$ & $\begin{array}{l}7.30 \pm 0.18^{P} \\
10.10 \pm 0.42\end{array}$ & $\begin{array}{l}5.62 \pm 0.36 \\
7.27 \pm 0.47\end{array}$ \\
\hline
\end{tabular}

Groups of 3 mice were infected with a dose of $10^{7}$ spores. A group of non-infected mice served as a control. *Total number of positive cell $\times 10^{6}$ in the spleen. Data represent mean \pm standard deviation. ${ }^{\mathrm{P}}$ The difference versus non-infected control is significant at $\mathrm{P}<0.05$.

Table 2. Flow cytometry analysis of splenocytes from IL-12 KO mice infected with Encephalitozoon intestinalis and E. cuniculi i.p. or p.o.

\begin{tabular}{|c|c|c|c|c|c|c|}
\hline & & \multirow[b]{2}{*}{ Days p.i. } & \multicolumn{2}{|c|}{ CD4+ } & \multicolumn{2}{|c|}{ CD8+ } \\
\hline & & & $\%$ Positive & Abs. No.* & \% Positive & Abs. No.* \\
\hline Control & & & $20.30 \pm 1.33$ & $16.84 \pm 0.98$ & $8.20 \pm 0.65$ & $6.80 \pm 0.56$ \\
\hline \multirow{3}{*}{$\begin{array}{l}\text { Encephalitozoon } \\
\text { intestinalis }\end{array}$} & & 7 & $17.50 \pm 0.81$ & $14.00 \pm 0.72^{P}$ & $10.40 \pm 0.68$ & $8.32 \pm 1.25^{\mathrm{P}}$ \\
\hline & i.p. & 14 & $15.30 \pm 053^{\mathrm{P}}$ & $15.31 \pm 0.61$ & $13.40 \pm 1.12^{\mathrm{P}}$ & $13.43 \pm 1.27^{\mathrm{P}}$ \\
\hline & p.o. & 7 & $18.20 \pm 0.78$ & $15.12 \pm 1.26$ & $11.60 \pm 0.72^{\mathrm{P}}$ & $9.62 \pm 1.36^{\mathrm{P}}$ \\
\hline \multirow{3}{*}{$\begin{array}{l}\text { Encephalitozoon } \\
\text { cuniculi }\end{array}$} & & $\frac{14}{7}$ & $\begin{array}{l}16.10 \pm 0.39 \\
18.60 \pm 1.32\end{array}$ & $\begin{array}{l}16.12 \pm 0.8 / \\
15.81 \pm 0.81\end{array}$ & $\frac{15.40 \pm 0.81}{9.30 \pm 0.12}$ & $\frac{13.09 \pm 0.71^{+}}{7.90 \pm 0.59}$ \\
\hline & i.p. & 14 & $15.30 \pm 0.39^{\mathrm{P}}$ & $12.24 \pm 0.49^{\mathrm{P}}$ & $10.10 \pm 0.36$ & $8.21 \pm 0.61$ \\
\hline & p.o. & $\begin{array}{c}7 \\
14\end{array}$ & $\begin{array}{r}19.20 \pm 0.57 \\
20.70 \pm 0.67\end{array}$ & $\begin{array}{c}15.74 \pm 0.69 \\
28.98 \pm 1.72^{\mathrm{P}}\end{array}$ & $\begin{array}{c}10.10 \pm 0.58 \\
15.60 \pm 0.26^{\mathrm{P}}\end{array}$ & $\begin{array}{c}8.28 \pm 0.74 \\
21.8 \pm 1.68^{\mathrm{P}}\end{array}$ \\
\hline
\end{tabular}

Groups of 3 mice were infected with a dose of $10^{7}$ spores. A group of non-infected mice served as a control. *Total number of positive cell $\times 10^{6}$ in the spleen. Data represent mean \pm standard deviation. ${ }^{\mathrm{P}}$ The difference versus non-infected control is significant at $\mathrm{P}<0.05$. 
Salát et al.: Infection of immunodeficient mice with Encephalitozoon spp.

Table 3. Flow cytometry analysis of splenocytes from BALB/c mice infected with Encephalitozoon intestinalis and E. cuniculi i.p. or p.o.

\begin{tabular}{|c|c|c|c|c|c|c|}
\hline & & & & & & \\
\hline & & Days p.i. & $\%$ Positive & Abs. No. * & \% Positive & Abs. No. ${ }^{*}$ \\
\hline Control & & & $23.60 \pm 0.12$ & $12.34 \pm 0.26$ & $9.60 \pm 0.21$ & $5.02 \pm 0.23$ \\
\hline Ence & i.p. & $\begin{array}{c}7 \\
14\end{array}$ & $\begin{array}{l}15.10 \pm 0.21^{\mathrm{P}} \\
16.60 \pm 0.11^{\mathrm{P}}\end{array}$ & $\begin{array}{c}15.64 \pm 1.75 \\
27.00 \pm 1.72^{\mathrm{P}}\end{array}$ & $\begin{array}{l}7.70 \pm 0.43^{\mathrm{P}} \\
9.50 \pm 0.42\end{array}$ & $\begin{array}{c}7.97 \pm 0.56^{\mathrm{P}} \\
15.64 \pm 1.31^{\mathrm{P}}\end{array}$ \\
\hline intestinalis & p.o. & $\begin{array}{c}7 \\
14\end{array}$ & $\begin{array}{c}20.40 \pm 0.47 \\
16.30 \pm 0.35^{\mathrm{P}}\end{array}$ & $\begin{array}{c}14.48 \pm 0.62 \\
19.64 \pm 1.91^{\mathrm{P}}\end{array}$ & $\begin{array}{c}9.10 \pm 0.22 \\
7.70 \pm 0.35^{\mathrm{P}}\end{array}$ & $\begin{array}{c}6.46 \pm 0.33 \\
9.27 \pm 0.76^{\mathrm{P}}\end{array}$ \\
\hline Encephalitozoon & i.p. & $\begin{array}{c}7 \\
14\end{array}$ & $\begin{array}{c}20.30 \pm 0.29 \\
11.40 \pm 0.33^{\mathrm{P}}\end{array}$ & $\begin{array}{l}16.84 \pm 1.41^{\mathrm{P}} \\
16.87 \pm 1.83^{\mathrm{P}}\end{array}$ & $\begin{array}{l}11.70 \pm 0.41^{\mathrm{P}} \\
18.90 \pm 0.58^{\mathrm{P}}\end{array}$ & $\begin{array}{c}9.71 \pm 0.83^{\mathrm{P}} \\
27.97 \pm 2.37^{\mathrm{P}}\end{array}$ \\
\hline cuniculi & p.o. & $\begin{array}{c}7 \\
14\end{array}$ & $\begin{array}{l}19.30 \pm 0.42^{\mathrm{P}} \\
18.80 \pm 0.62^{\mathrm{P}}\end{array}$ & $\begin{array}{c}12.53 \pm 1.12 \\
21.62 \pm 1.79^{P}\end{array}$ & $\begin{array}{l}9.30 \pm 0.36 \\
8.70 \pm 0.27\end{array}$ & $\begin{array}{c}5.95 \pm 0.41 \\
10.00 \pm 1.17^{\mathrm{P}}\end{array}$ \\
\hline
\end{tabular}

Groups of 3 mice were infected with a dose of $10^{7}$ spores. A group of non-infected mice served as a control. *Total number of positive cell $\times 10^{6}$ in the spleen. Data represent mean \pm standard deviation. ${ }^{\mathrm{P}}$ The difference versus non-infected control is significant at $\mathrm{P}<0.05$.

Table 4. Flow cytometry analysis of splenocytes from C57BL/6 mice infected with Encephalitozoon intestinalis and E. cuniculi i.p. or p.o.

\begin{tabular}{|c|c|c|c|c|c|c|}
\hline & & \multirow[b]{2}{*}{ Days p.i. } & \multicolumn{2}{|c|}{ CD4+ } & \multicolumn{2}{|c|}{ CD8+ } \\
\hline & & & $\%$ Positive & Abs. No. ${ }^{*}$ & $\%$ Positive & Abs. No. ${ }^{*}$ \\
\hline Control & & & $21.90 \pm 1.72$ & $11.01 \pm 1.09$ & $7.40 \pm 0.56$ & $3.72 \pm 0.31$ \\
\hline \multirow{3}{*}{$\begin{array}{l}\text { Encephalitozoon } \\
\text { intestinalis }\end{array}$} & i.p. & $\begin{array}{c}7 \\
14\end{array}$ & $\begin{array}{l}14.50 \pm 0.92^{\mathrm{P}} \\
13.70 \pm 054^{\mathrm{P}}\end{array}$ & $\begin{array}{l}14.50 \pm 0.83^{\mathrm{P}} \\
15.33 \pm 0.72^{\mathrm{P}}\end{array}$ & $\begin{array}{c}8.90 \pm 0.79 \\
1070 \pm 123^{\mathrm{P}}\end{array}$ & $\begin{array}{c}8.90 \pm 0.85^{\mathrm{P}} \\
11.97 \pm 0.96^{\mathrm{P}}\end{array}$ \\
\hline & & 7 & $19.40 \pm 0.89$ & $11.67 \pm 1.17$ & $8.80 \pm 0.63$ & $5.22 \pm 0.86$ \\
\hline & p.o. & 14 & $16.30 \pm 0.40^{\mathrm{P}}$ & $34.03 \pm 1.98^{\mathrm{P}}$ & $8.20 \pm 0.92$ & $17.12 \pm 1.32^{\mathrm{P}}$ \\
\hline \multirow{2}{*}{$\begin{array}{l}\text { Encephalitozoon } \\
\text { cuniculi }\end{array}$} & i.p. & $\begin{array}{c}7 \\
14 \\
\end{array}$ & $\begin{array}{c}20.10 \pm 1.43 \\
13.50 \pm 0.50^{\mathrm{P}}\end{array}$ & $\begin{array}{l}19.29 \pm 0.92^{\mathrm{P}} \\
16.60 \pm 0.60^{\mathrm{P}}\end{array}$ & $\begin{array}{l}17.50 \pm 0.45^{\mathrm{P}} \\
24.90 \pm 1.31^{\mathrm{P}}\end{array}$ & $\begin{array}{c}16.80 \pm 073^{\mathrm{P}} \\
30.62 \pm 2.21^{\mathrm{P}}\end{array}$ \\
\hline & p.o. & $\begin{array}{c}7 \\
14 \\
\end{array}$ & $\begin{array}{r}18.30 \pm 0.68 \\
17.50 \pm 0.58^{\mathrm{P}}\end{array}$ & $\begin{array}{r}12.24 \pm 0.80 \\
31.29 \pm 1.83^{\mathrm{P}}\end{array}$ & $\begin{array}{c}8.30 \pm 0.42 \\
10.20 \pm 0.47^{P}\end{array}$ & $\begin{array}{c}5.54 \pm 0.85 \\
18.21 \pm 1.79^{\mathrm{P}}\end{array}$ \\
\hline
\end{tabular}

Groups of 3 mice were infected with a dose of $10^{7}$ spores. A group of non-infected mice served as a control. *Total number of positive cell $\times 10^{6}$ in the spleen. Data represent mean \pm standard deviation. ${ }^{\mathrm{P}}$ The difference versus non-infected control is significant at $\mathrm{P}<0.05$.

Table 5. Flow cytometry analysis of splenocytes from SCID mice reconstituted with splenocytes from IFN- $\gamma$ KO mice and infected with Encephalitozoon intestinalis or E. cuniculi i.p. and p.o.

\begin{tabular}{|l|l|l|c|c|c|c|}
\hline & & & \multicolumn{2}{|c|}{ CD4+ } & \multicolumn{2}{c|}{ CD8+ } \\
& & Days p.i. & \% Positive & Abs. No. & \% Positive & Abs. No. * \\
\hline Control & & & $19.70 \pm 0.65$ & $2.36 \pm 0.09^{\mathrm{P}}$ & $6.50 \pm 0.68$ & $0.78 \pm 0.25$ \\
\hline \multirow{3}{*}{$\begin{array}{l}\text { Encephalitozoon } \\
\text { intestinalis }\end{array}$} & \multirow{2}{*}{ i.p. } & 20 & $23.20 \pm 1.23^{\mathrm{P}}$ & $3.71 \pm 0.24^{\mathrm{P}}$ & $10.60 \pm 1.13^{\mathrm{P}}$ & $1.69 \pm 0.41^{\mathrm{P}}$ \\
\cline { 2 - 7 } & \multirow{2}{*}{ p.o. } & 20 & $10.00 \pm 0.53^{\mathrm{P}}$ & $1.31 \pm 0.21$ & $5.20 \pm 0.69$ & $0.68 \pm 0.07$ \\
\hline \multirow{3}{*}{$\begin{array}{l}\text { Encephalitozoon } \\
\text { cuniculi }\end{array}$} & \multirow{2}{*}{ i.p. } & $20.10 \pm 2.1$ & $3.05 \pm 0.33$ & $9.30 \pm 0.82^{\mathrm{P}}$ & $1.39 \pm 0.13^{\mathrm{P}}$ \\
\cline { 2 - 7 } & \multirow{2}{*}{ p.o. } & 25 & $11.50 \pm 0.68^{\mathrm{P}}$ & $1.49 \pm 0.64$ & $3.90 \pm 0.06^{\mathrm{P}}$ & $0.50 \pm 0.09$ \\
\hline & & 20 & $17.40 \pm 0.39$ & $2.08 \pm 0.14$ & $7.80 \pm 0.97$ & $0.93 \pm 0.16$ \\
& & $18.80 \pm 0.64^{\mathrm{P}}$ & $1.45 \pm 0.21$ & $6.30 \pm 0.35$ & $0.69 \pm 0.03$ \\
\hline
\end{tabular}

Groups of 3 mice were reconstituted by the i.p. injection of $10^{7}$ splenocytes from IF- $\gamma$ KO mice. Seven days after reconstitution the mice were infected with a dose of $10^{7}$ spores. Reconstituted uninfected group served as a control. *Total number of positive cell $\times 10^{6}$ in the spleen. Data represent mean \pm standard deviation. ${ }^{\mathrm{P}}$ The difference versus non-infected control is significant at $\mathrm{P}<0.05$.

In IL-12 KO mice infected either with $E$. intestinalis or E. cuniculi, the marked significant increase of CD8+ cells was observed particularly on day 14 p.i. $(\mathrm{P}<0.05)$, except in mice inoculated with E. cuniculi i.p. (Table 2). While in E. intestinalis-infected mice the absolute num- bers of CD8+ cells were doubled on day 14 p.i. regardless of the route of infection, the number of these cells in E. cuniculi p.o.-infected IL-12 KO mice was at this time point three-times higher than in the control, noninfected group, again due to marked splenomegaly. Also 
BALB/c

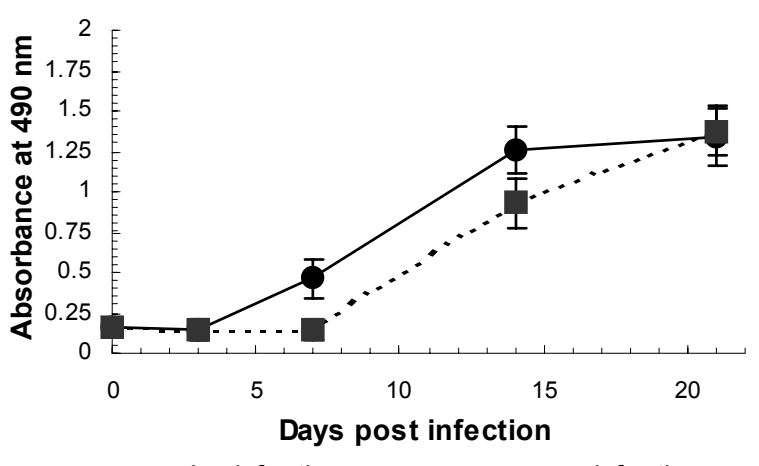

$\longrightarrow$ i.p. infection _..... p.o. infection
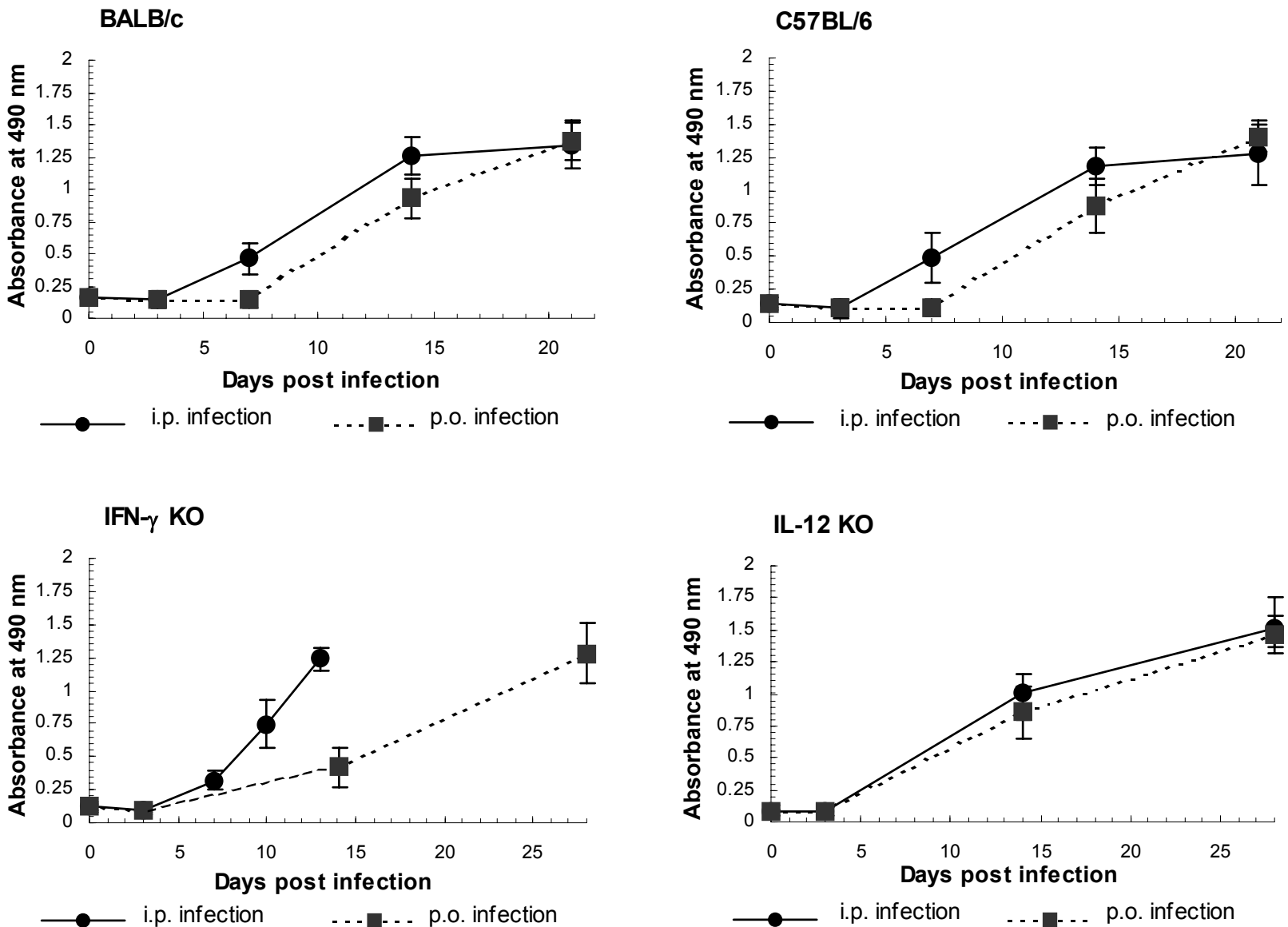

$\longrightarrow$ i.p. infection _..- - p.o. infection

\section{IL-12 KO}

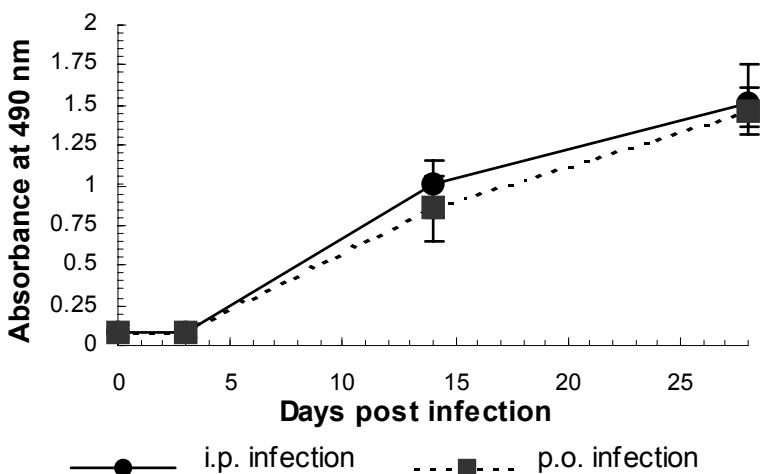

Fig. 5. Production of specific serum antibodies by BALB/c, C57BL/6, IFN- $\gamma$ KO and IL-12 KO mice infected with Encephalitozoon intestinalis i.p. or p.o. Group of 3 mice was infected with $10^{7}$ spores, blood was collected from retroorbital sinus. Microsporidia-specific antibodies were determined by an ELISA. Each value represents the mean of three samples measured in triplication $\pm \mathrm{SD}$.

the percentage of these cells increased almost twofold. The rise of CD8+ T cells was the lowest in the group of IL-12 KO mice infected with E. cuniculi i.p., the only group which succumbed to the infection. The increase of CD8+ T lymphocytes was accompanied with the decrease of the percentage of CD4 $+\mathrm{T}$ cells with one exception on day 14 post p.o. infection with E. cuniculi. Flow cytometry analysis performed on immunocompetent BALB/c and C57BL/6 mice showed that absolute numbers of $\mathrm{CD} 4+$ and $\mathrm{CD} 8+\mathrm{T}$ cells in the spleen were rising during the infection with $E$. intestinalis or $E$. cuniculi (Tables 3, 4).

In SCID mice reconstituted with splenocytes from IFN- $\gamma$ KO mice, only a transient but significant increase in both relative and absolute numbers of CD8+ cells was observed on day 20 p.i. with E. intestinalis regardless of the route of infection $(\mathrm{P}<0.05)$ (Table 5). Some increase was also recorded in CD4+ cells on day 20 p.i., followed by a decrease in later time points.

The kinetics of microsporidia-specific antibodies in IFN- $\gamma \mathrm{KO}$ and IL-12 KO mice infected with E. intestinalis either i.p. or p.o. was compared with that of their wild-type counterparts BALB/c and C57BL/6 mice. In both wild-type strains the onset of specific antibodies in sera was delayed in perorally infected mice reaching a similar value of absorbance with mice infected i.p. on day 21 p.i. In IL-12 KO mice the antibody kinetics was almost the same after i.p. or p.o. infection. In IFN- $\gamma \mathrm{KO}$ mice anti-microsporidial antibodies increased rapidly in mice infected i.p., following peroral infection the antibody rise was the slowest of all experimental groups (Fig. 5). Identical experiments performed with E. cuniculi infection provided similar results (data not shown).

\section{DISCUSSION}

Protective immunity against microsporidial infection was shown to be mediated by cytotoxic CD8+ T lymphocytes (Khan et al. 1999) and the cytokines IFN- $\gamma$ and IL-12 were important for its development (Khan and Moretto 1999). These fundamental data were obtained in an artificial (intraperitoneal) infection of mice with Encephalitozoon cuniculi spores. Recently, it has been shown that in addition to $\mathrm{CD} 8+\mathrm{T}$ cells, CD4+ $\mathrm{T}$ 
lymphocytes can mediate protective immunity against natural (peroral) E. cuniculi infection when transferred to otherwise susceptible SCID mice (Braunfuchsová et al. 2002). The aim of the present study was to extend these data by those obtained with another Encephalitozoon species, E. intestinalis. While a similar role of CD4+ $\mathrm{T}$ lymphocytes has been demonstrated in the protection against peroral $E$. intestinalis infection (Salát et al. 2002), a delay of time to death was recorded after peroral infection with $E$. intestinalis compared with $E$. cuniculi infection. Results obtained in IFN- $\gamma \mathrm{KO}$ mice indicate the crucial role of this cytokine in the development of protective immunity against both pathogens inoculated either i.p. or p.o. The important role of IFN- $\gamma$ in the protective immunity against $E$. cuniculi was documented by Khan and Moretto (1999), using i.p. infection of IFN- $\gamma \mathrm{KO}$ mice. Resistance to E. intestinalis infection was also shown to be associated with IFN- $\gamma$, but in IFN- $\gamma$ receptor $\mathrm{KO}$ mice a chronic, non-lethal infection developed after peroral inoculation of spores (El Fakhry et al. 2001). The difference between the lethal outcome of $E$. intestinalis infection in IFN- $\gamma \mathrm{KO}$ mice and not lethal chronic infection of IFN- $\gamma$ receptor KO mice can be explained by different virulence of $E$. intestinalis strains that were cultured in different conditions. The other, less probable explanation can be the existence of various IFN- $\gamma$ receptors that were not completely affected in IFN- $\gamma$ receptor $\mathrm{KO}$ mice.

The role of IL-12 in the protective anti-microsporidial immunity seems to be less significant. Of four groups of IL-12 KO mice infected with E. cuniculi or $E$. intestinalis i.p. or p.o., only i.p. infection with $E$. cuniculi killed mice with very long MST. These results are in agreement with those published by Khan and Moretto (1999), who used the different (p40/) strain of IL-12 KO mice or IL-12-neutralising antibody. In contrast to the results in IFN- $\gamma \mathrm{KO}$ mice, IL-12 KO mice survived p.o. infection with both Encephalitozoon species and i.p. infection with E. intestinalis. The work by Braunfuchsová et al. (1999) documented that IL-12 can be induced by $E$. cuniculi infection of SCID mice, while in similarly infected BALB/c mice it was not detected.

The fact that IFN- $\gamma$ KO mice succumbed to the microsporidial infection even earlier than SCID mice led to the experiment in which SCID mice were reconstituted with splenocytes from naive IFN- $\gamma \mathrm{KO}$ mice. Reconstituted mice died later than SCID mice or IFN- $\gamma$ $\mathrm{KO}$ mice in all four E. cuniculi or E. intestinalis i.p. or p.o. infected groups. These results indicate that IFN- $\gamma$ produced by SCID mouse cells (i.e., NK cells) stimulates transferred $\mathrm{T}$ lymphocytes to differentiate into effector cells, which are able to control the infection partially. This hypothesis is further supported by the results of flow cytometry analysis of reconstituted mice. After infection, a transient increase of CD8+ cells was observed.
For the interpretation of flow cytometry analysis both absolute and relative values for CD4+ and CD8 $+\mathrm{T}$ cell counts were used due to the development of splenomegaly during the acute phase of infection. Results of immunophenotyping of spleen cells from both infected IFN- $\gamma$ and IL-12 KO mice were in agreement with the outcome of the infection. In IFN- $\gamma$ KO mice, which developed a lethal Encephalitozoon infection, both relative and absolute numbers of CD8 $+\mathrm{T}$ lymphocytes largely decreased, whereas in IL-12 KO mice that survived the infection, a marked increase in numbers of these cells was recorded. This supports the idea that IL-12 is not essential for the differentiation of CD8 $+\mathrm{T}$ effectors, the increase of which is observed during microsporidial infections (Khan et al. 1999, Braunfuchsová et al. 2001).

Observation of the kinetics of microsporidia-specific antibodies showed similar pattern in BALB/c, C57BL/6 and IL-12 KO mice. In IFN- $\gamma$ KO mice, infected with $E$. intestinalis i.p., the antibody production increased the most rapidly, probably due to accelerated replication of the parasite in the host. None of the cytokines in question was necessary for the production of anti-microsporidial antibodies.

From this study and other recently published papers it can be concluded that identical immune mechanisms control the infection with both closely related Encephalitozoon species. Whereas IFN- $\gamma$ is the essential cytokine for induction of protective anti-microsporidial immunity irrespective of the route of infection, IL-12 can contribute to the polarisation of the immune response towards Th1 cytokines, but it is not essential for the control of peroral infection with both E. cuniculi and $E$. intestinalis microsporidians. IFN- $\gamma$ produced by $\mathrm{NK}$ cells contributes to the development of effector mechanisms controlling the infection, but its effect is not sufficient to cure the infection. One of the important questions to be answered is the role of IFN- $\gamma$ and activated macrophages in the control of these emerging pathogens.

Acknowledgements. The study was supported by grant no. A6022101 from the Grant Agency of the Academy of Sciences of the Czech Republic, by grant no. 524/03/D167 from the Grant Agency of the Czech Republic and by grant no. MSM-123100003 of the Ministry of Education, Youth and Sports of the Czech Republic. This study is a part of research project of the Institute of Parasitology, Academy of Sciences of the Czech Republic (Z6 022 909) Thuy Le was supported by the BRAVO! Program (MIRT T37TW00036-01). All of the experimental procedures were done in accordance with the national law on the use of experimental animals, safety and use of pathogenic agents. 


\section{REFERENCES}

BRAUNFUCHSOVÁ P., KOPECKÝ J., DITRICH O., KOUDELA B. 1999: Cytokine response to infection with the microsporidian Encephalitozoon cuniculi. Folia Parasitol. 46: 91-95.

BRAUNFUCHSOVÁ P., SALÁT J., KOPECKÝ J. 2001: CD8+ T lymphocytes protect SCID mice against Encephalitozoon cuniculi infection. Int. J. Parasitol. 31: 681-686.

BRAUNFUCHSOVÁ P., SALÁT J., KOPECKÝ J. 2002: Comparison of the significance of CD4+ and CD8+ T lymphocytes in the protection of mice against Encephalitozoon cuniculi infection. J. Parasitol. 88: 797-799.

CALI A., KOTLER D.P., ORENSTEIN J.M. 1993: Septata intestinalis n. g., n. sp., an intestinal microsporidian associated with chronic diarrhoea and dissemination in AIDS patients. J. Eukaryot. Microbiol. 40: 101-112.

DIDIER E.S. 1995: Reactive nitrogen intermediates implicated in the inhibition of Encephalitozoon cuniculi (phylum Microspora) replication in murine peritoneal macrophages. Parasite Immunol. 17: 405-412.

DIDIER E.S., ROGERS L.B., ORENSTEIN J.M., BAKER M.D., VOSSBRINCK C.R., VAN GOOL T., HARTSKEERL R., SOAVE R., BEAUDET L.M. 1996: Characterization of Encephalitozoon (Septata) intestinalis isolates cultured from nasal mucosa and bronchoalveolar lavage fluids of two AIDS patients. J. Eukaryot. Microbiol. 43: 34-43.

DIDIER E.S., SNOWDEN K.F., SHADDUCK J.A. 1998: Biology of microsporidian species infecting mammals. Adv. Parasitol. 40: 283-320.

El FAKHRY Y., ACHBAROU A., DESPORTES-LIVAGE I., MAZIER D. 1998: Encephalitozoon intestinalis: humoral responses in interferon-gamma receptor knockout mice infected with a microsporidium pathogenic in AIDS patients. Exp. Parasitol. 89: 113-121.

El FAKHRY Y., ACHBAROU A., DESPORTES I., MAZIER D. 2001: Resistance to Encephalitozoon intestinalis is associated with interferon-gamma and interleukin-2 cytokines in infected mice. Parasite Immunol. 23: 297-303.

GANNON J. 1980: The course of infection of Encephalitozoon cuniculi in immunodeficient and immunocompetent mice. Lab. Anim. 14: 189-192.
KHAN I.A., MORETTO M. 1999: Role of gamma interferon in cellular immune response against murine Encephalitozoon cuniculi infection. Infect. Immun. 67: 1887-1893.

KHAN I.A., MORETTO M., WEISS L.M. 2001: Immune response to Encephalitozoon cuniculi infection. Micr. Infect. 3: 401-405.

KHAN I.A., SCHWARTZMAN J.D., KASPER L.H., MORETTO M. 1999: CD8+ CTLs are essential for protective immunity against Encephalitozoon cuniculi infection. J. Immunol. 162: 6086-6091.

KOUDELA B., LOM J., VÍTOVEC J., KUČEROVÁ Z., DITRICH O., TRÁVNÍČEK J. 1994: In vivo efficacy of albendazole against Encephalitozoon cuniculi in SCID mice. J. Eukaryot. Microbiol. 41: 49-50.

MORETTO M., CASCIOTTI L., DURELL B., KHAN I. 2000: Lack of CD4+ T cells does not affect induction of CD8+ T-cell immunity against Encephalitozoon cuniculi infection. Infect. Immun. 68: 6223-6232.

MORETTO M., DURELL B., SCHWARTZMAN J.D., KHAN I.A. 2001: Gamma delta T cell-deficient mice have a down-regulated $\mathrm{CD} 8+\mathrm{T}$ cell immune response against Encephalitozoon cuniculi infection. J. Immunol. 166: 7389-7397.

ORENSTEIN J.M. 1991: Microsporidiosis in the acquired immunodeficiency syndrome. J. Parasitol. 77: 843-864.

ORENSTEIN J.M., TENNER M., KOTLER D.P. 1992: Localization of infection by the microsporidian Enterocytozoon bieneusi in the gastrointestinal tract of AIDS patients with diarrhea. AIDS 6: 195-197.

SALÁT J., BRAUNFUCHSOVÁ P., KOPECKÝ J., DITRICH O. 2002: Role of CD4+ and CD8+ T lymphocytes in the protection of mice against Encephalitozoon intestinalis infection. Parasitol. Res. 88: 603-608.

SCHMIDT E.C., SHADDUCK J.A. 1983: Murine encephalitozoonosis model for studying the host-parasite relationship of chronic infection. Infect. Immun. 40: 936-942.

WEBER R., BRYAN R.T., SCHWARTZ D.A., OWEN R.L. 1994: Human microsporidial infections. Clin. Microbiol. Rev. 7: 426-461.

Accepted 10 June 2004 